\title{
Infralittoral molluscs from the Scilla cliff (Strait of Messina, Central Mediterranean)
}

\author{
Salvatore Giacobbe' \& Walter Renda ${ }^{2}$
}

'Department of Chemical, Biological, Pharmaceutical and Environmental Sciences, University of Messina, Viale F. Stagno d'Alcontres 31, 98166 Messina, Italy; e-mail: sgiacobbe@unime.it

${ }^{2}$ Via Bologna, 18/A, 87032 Amantea (Cosenza), Italy; e-mail: w.renda1@tin.it

ABSTRACT

\begin{abstract}
The mollusc taxocoenosis characterizing the photophilic zone of the Scilla cliff (Strait of Messina, Central Mediterranean) has been described on hard bottom samples from 6, 16 and $24 \mathrm{~m}$ depth. Seasonality has been evaluated by replicates carried out in autumn and spring. Overall, 229 benthic taxa have been recorded, 87 of which occurred in both seasons, while 109 were exclusively recorded in spring and 29 only in autumn. Specimen abundance also notably decreased from autumn to spring (1581 and 892 individuals, respectively). Depth scarcely affected the species distribution, probably due to water transparency, thermal homogeneity, and nutrient mixing. The recorded species cannot be all assigned to the photophilic rocky habitat, since ubiquitous taxa, organisms of other habitats settled in micro-enclaves, and juveniles of not established species have been frequently recorded. The role of algal covering as larval collector from disparate habitats is confirmed, as also proved by the high occurrence of planktonic molluscs (14 species) in all the examined samples. The whole mollusc taxocoene, whose diversity is high with respect to other areas at comparable latitudes, showed a marked western footprint, in accordance with the known biogeographic peculiarities of the Messina Strait.
\end{abstract}

\section{INTRODUCTION}

Mediterranean biodiversity has in the Strait of Messina (MS) one of the most relevant hot spot. High diversity is here coupled with peculiar associations which made necessary to consider such area as a distinct "microsector" inside the biogeographical Mediterranean subdivision (Bianchi et al., 2012).

Molluscs are probably the most known Phylum from the MS area, counting 827 species in the updated check-list of Italian seas (http://www.sibm. it/CHECKLIST/menu\%20checklist\%20I.htm).
Present knowledge, nevertheless, suffers the lack of extensive studies, so that only some major taxa and habitats, as the "Opisthobranch fauna" from brackish areas, have been exhaustively investigated (Vitale et al., 2016). Hard bottom mollusc biodiversity, in the Sicilian MS side has been explored on the local scale in the upper Infralittoral of Messina, (Cosentino \& Giacobbe, 2015). In the Calabrian side, the Infralittoral mollusc taxocoene has been recently investigated in the Capo d'Armi cliff, south of Reggio Calabria (Giacobbe \& Renda, 2018). The Scilla cliff, north of Reggio Calabria, has been frequently cited in malacological literature and in re- 
cent years has provided several new mollusc species and some probable endemism (Bogi \& Campani, 2007; Buzzurro \& Russo, 2007; Bogi \& Bartolini, 2008; Tisselli et al., 2009; Smriglio \& Mariottini, 2013; Romani \& Scuderi, 2015). Some attention also received the spreading of not native species (Crocetta et al., 2009). Current knowledge, nevertheless, is almost inorganic, as it refers to records that in general are not adequately contextualized, or carried out without a precise sampling plan (see Vazzana, 2010).

First data on the mollusc taxocoenosis, that characterize the photophilic zone of the Scilla cliff, are reported in this paper, as a contribution to the knowledge of the mollusc local biodiversity. The aim of the study is to provide a baseline for monitoring benthic assemblages of this crucial area, which could dramatically be affected by ongoing climate change.

\section{MATERIAL AND METHODS}

\section{Study area}

The Scilla cliff (Fig. 1), known since the most ancient age due to the strong currents and whirls making dangerous the navigation (Androsov et al., 1996), delimits the northern mouth of the MS into the Calabrian side. Widely described and figured in the popular literature, it has been widely investigated in the geological and seismological field (Ferranti et al., 2007; Casalbore et al., 2014), but very few studies have been carried out about the seabed ecology. Quantitative data on benthic assemblages

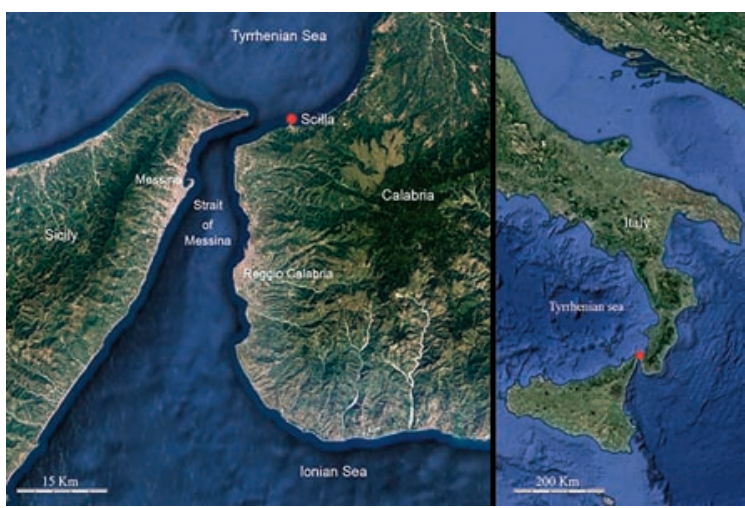

Figure 1. Study area. from a granitic shoal at 35-60 $\mathrm{m}$ depth, have been focused on gorgonians (Mistri \& Ceccherelli, 1994) and their mass mortality (Mistri \& Ceccherelli, 1995). Infralittoral hard bottom assemblages have been investigated with methodological purposes, but without providing lists of species (Mistri \& Rossi, 2000).

\section{Sampling}

The investigations concerned three sites, located about $200 \mathrm{~m}$ away from each other. In each site, three bathymetric levels $(6,16$, and $24 \pm 2 \mathrm{~m}$ depth) were sampled, each performed by three replicates about $20 \mathrm{~m}$ away from each other. Sampling has been repeated in autumn (I time) and spring (II time), to evaluate seasonality. The samples were collected by scraping $30 \times 30 \mathrm{~cm}$ surface of rocky substrate, separately gathered in $0.1 \mathrm{~mm}$ mash sampling nets, and stored in ethanol $75 \%$. In laboratory, mollusc fauna was sorted under stereomicroscope and the specimens determined at species level, as far as possible. Abundance of taxa per sample was evaluated on the three replicates pooled. Pelagic gastropods trapped in the algal covering, have also been sorted and classified, and qualitative data have been reported as a further contribution to the mollusc local biodiversity.

Most relevant species have been photographed by means of USB DCM130 digital camera mounted on a binocular microscope, and the photos processed by Photoshop software.

Nomenclature followed WoRMS (http://www. marinespecies.org/), updated at 2018-06-30.

\section{RESULTS}

\section{Benthic species}

Overall, 2473 living specimens have been collected from the mollusc taxocoenosis, belonging to 229 benthic taxa, 208 of which determined at the species level (Table 1). The species were almost irregularly distributed between the two seasons, strongly decreasing from autumn to spring (196 and 116 species, respectively). Specimen abundance also notably decreased (1581 and 892 individuals, respectively). A total of 87 established taxa was in- 
dividuated, whilst 109 taxa were exclusively recorded in spring compared to the 29 ones found in autumn. The greatest part of not established taxa counted a low number of specimens, 63 of which, since represented by a specimen alone, should be considered as occasional.

A marked seasonality, by contrast, might characterize some of the not established species which counted more than 10 individuals (Fig. 2), namely the autumnal Chauvetia lefebvrii (Maravigna, 1840), Pusillina inconspicua (Alder, 1844), Striarca lactea (Linnaeus, 1758), Eatonina ochroleuca (Brusina, 1869), and the vernal Rissoella diaphana (Alder, 1848), Setia turriculata Monterosato, 1884, Sinezona cingulata (Costa O.G., 1861), Setia cfr. turriculata. The latter two species are present in figure 2, since they account for more than 20 individuals. The problematic taxon Setia cfr. turriculata, in particular, is the third most abundant species, after Alvania lineata Risso, 1826 and Bittium latreillii (Payraudeau, 1826) (175 and 126 individuals, respectively). None of the 34 most abundant species were found exclusively in the autumn.

The bathymetric distribution, as detailed in Fig. 3 , showed weak differences between 6,16 , and 24 $\mathrm{m}$ depth levels, sharing 48 species, including the 22 most abundant ones ( $\geq 32$ specimens). The first, Bittium latreillii, second, Alvania lineata, fourth, $R e$ tusa truncatula (Bruguiere, 1792), and fifth (Haminoea $\mathrm{sp}$.) most abundant taxa, showed nevertheless a marked prevalence at the deeper level, unlike the third, Setia cfr. turriculata, and sixth taxa, Cerithium renovatum Monterosato, 1884, which dominated at the shallower depth. Among the other twelve most abundant taxa ( $\geq 20$ specimens), ten species settled more or less preferentially at -6 $\mathrm{m}$, whilst Tritia cuvierii (Payraudeau, 1826) and Setia ambigua (Brugnone, 1873) were equally abundant from $-6 \mathrm{~m}$ to $-24 \mathrm{~m}$ (the latter one was scarce at intermediate depth).

The total number of benthic mollusc species, $\mathrm{S}$, and individuals, $\mathrm{N}$, according to season and depth, is shown in figure 4 . Seasonality notably affected abundances, higher in autumn than in spring (1582 and 1043 individuals, respectively). Average abundance regularly increased with depth in autumn, from $-6 \mathrm{~m}(76.0 \pm 33.5$ ind./site $)$ to $-24 \mathrm{~m}$ (277.7 \pm 20.8 ind./site). A different trend has been observed in spring, since the lowest values have been recorded at $-12 \mathrm{~m}(61.7 \pm 32.7 \mathrm{ind}$./site $)$ and the highest ones at $-24 \mathrm{~m}(204 \pm 131.2 \mathrm{ind} . / \mathrm{site})$. The number of species also increased with depth, although less markedly in spring ( $\min 20.0 \pm 10.2$; $\max 49.3 \pm 18.0$ ) rather than in autumn (min $22.7 \pm 11.4$; $\max 93.7 \pm 8.4$ ).

The Shannon diversity index H' also showed the highest values in autumn, gradually increasing with depth in both seasons (Fig. 5). The minimum $(2.1 \pm 0.6)$ was recorded in spring, at $6 \mathrm{~m}$ depth, while the maximum $(4.1 \pm 0.1)$ in autumn, at $24 \mathrm{~m}$ depth. Equitability J' index was uniformly high in autumn, ranging from $0.86 \pm 0.0$ at $-6 \mathrm{~m}$, to $0.9 \pm 0.0$ both at 12 and $24 \mathrm{~m}$, whilst it was more variable in spring, with minimum at $-6 \mathrm{~m}$ and maximum at -12 $\mathrm{m}(0.7 \pm 0.1$ and $0.9 \pm 0.0$, respectively).

All the most abundant and/or frequent taxa found in the subtidal cliff of Scilla are widely represented in the whole Mediterranean Sea, but a secondary cluster of west Mediterranean characteristic species is also recognizable. The marginellids Granulina marginata (Bivona, 1832) e Gibberula philippi (Monterosato, 1878), for example, are known in the western basins (Gofas, 1990; Boyer et al., 2002), although unconfirmed records have been given from some eastern localities (Özturk et al, 2014). The occurrence of both species in the MS has been recently reported for Capo d'Armi by Giacobbe \& Renda (2018), which suggested as Gibberula philippi "might be represented by a not yet investigated species complex".

Some other species, although quantitatively negligible, provide further indications of a marked western affinity, as for example the Caraibic sea hare, Aplysia parvula Mörch, 1863, whose present record from Scilla after that of Capo d'Armi (Giacobbe and Renda, 2018) suggested the species is widely present in the MS area. The same symmetric occurrence in Scilla and Capo d'Armi has concerned the amphi-atlantic ascoglossan Ascobulla fragilis (Jeffreys, 1856).

Another poorly known species is Pyrunculus hoernesi (Weinkauff, 1866), having eastern Atlantic distribution and especially reported from the $\mathrm{Ca}$ narian and Capo Verde (Tringali, 1993; Ortea et al., 2009). The present record confirmed the occurrence of this species in the MS, that before now could only be deduced from the young specimens figured by Scaperrotta et al. (2011).

Ammonicera nodulosa Oliver et Rolán, 2015, from Spanish Atlantic, has been later reported from 


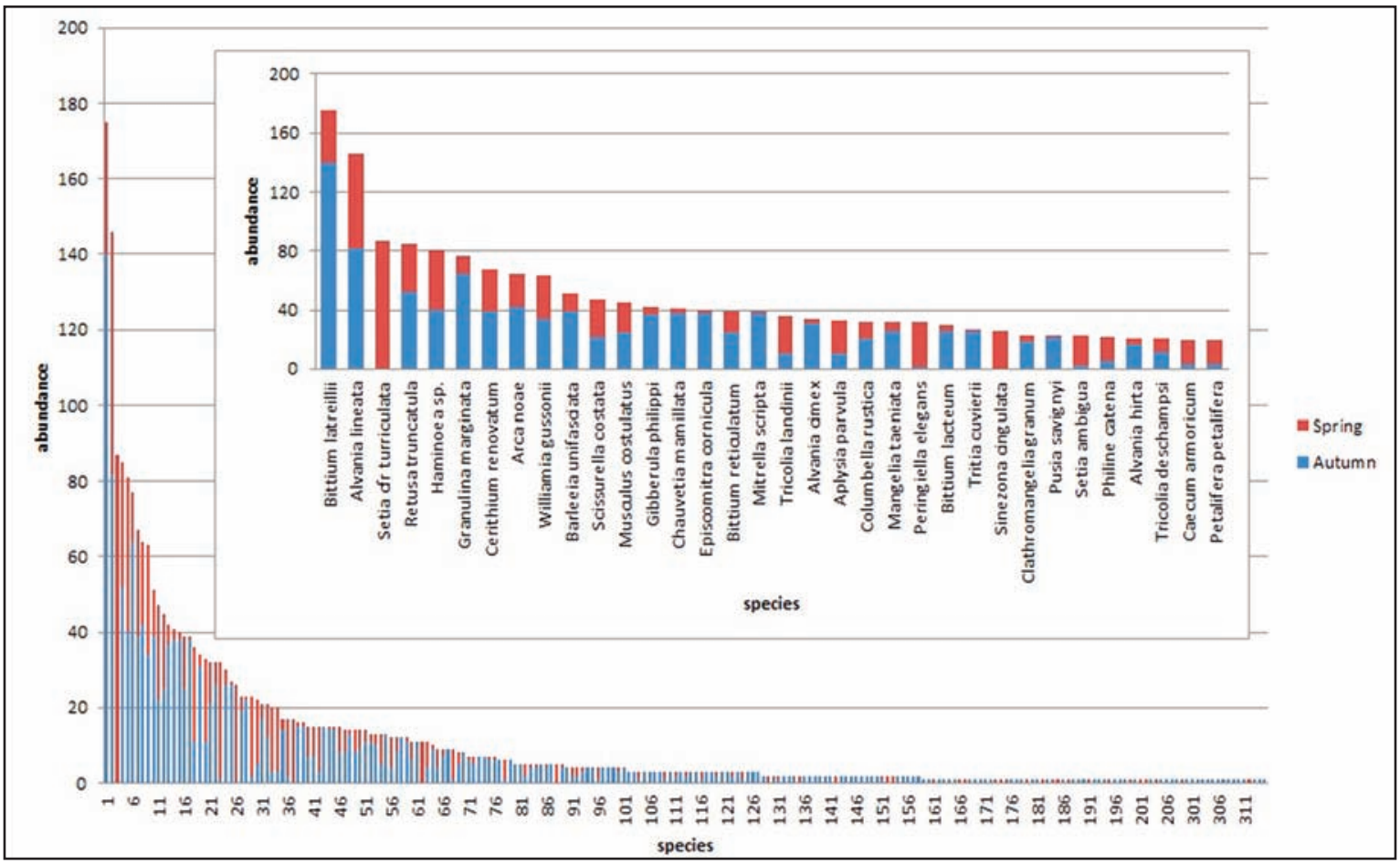

Figure 2. Rank ordination of species (decreasing number of specimens for species) and detail of the 22 most abundant species ( $>20$ specimens), according to their spring (red) and autumn (blue) abundance.

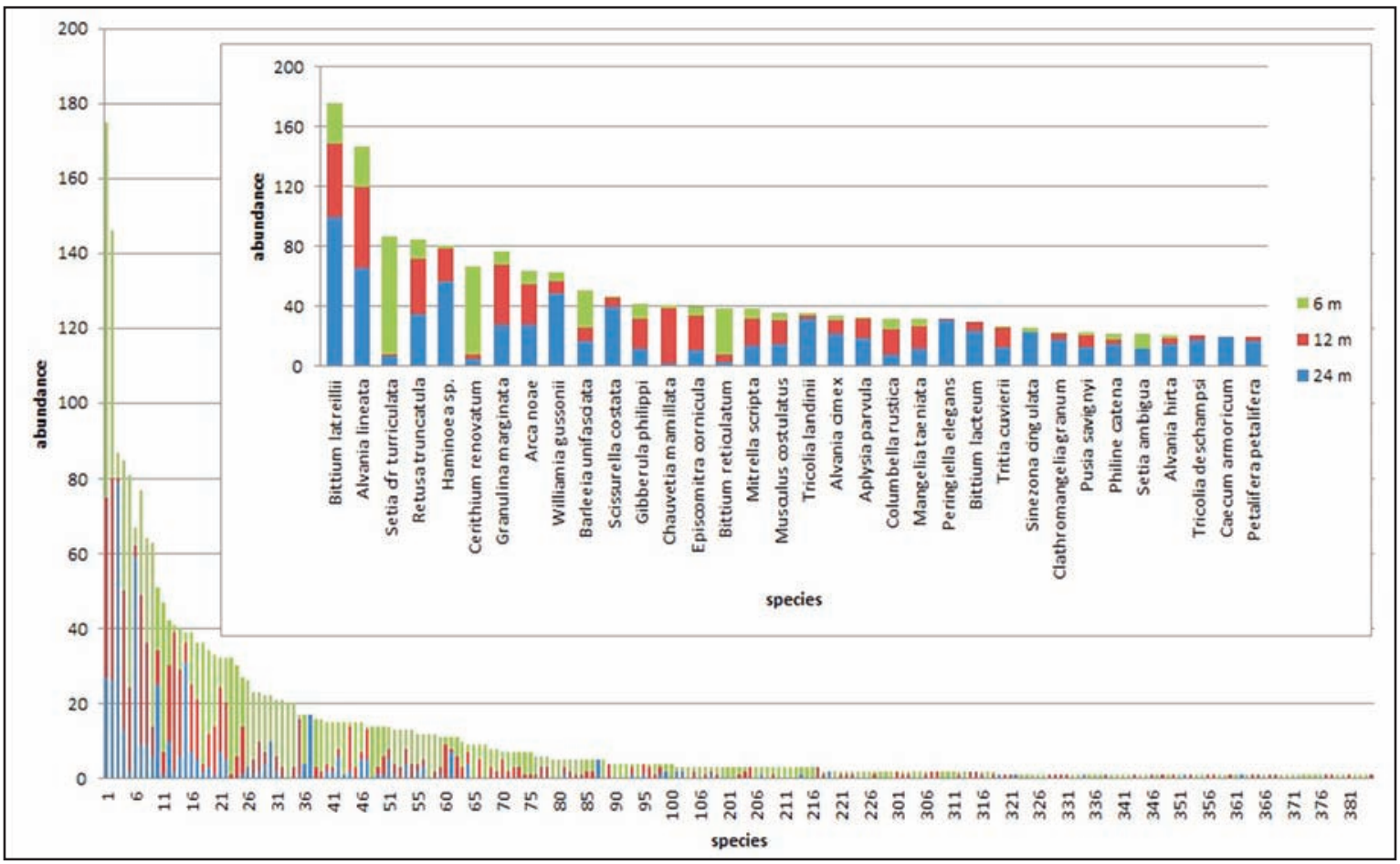

Figure 3. Rank ordination of species (decreasing number of specimens for species) and detail of the 22 most abundant species (> 20 specimens), according to the lower (green), intermediate (red), and deeper (blue) bathymetric levels. 


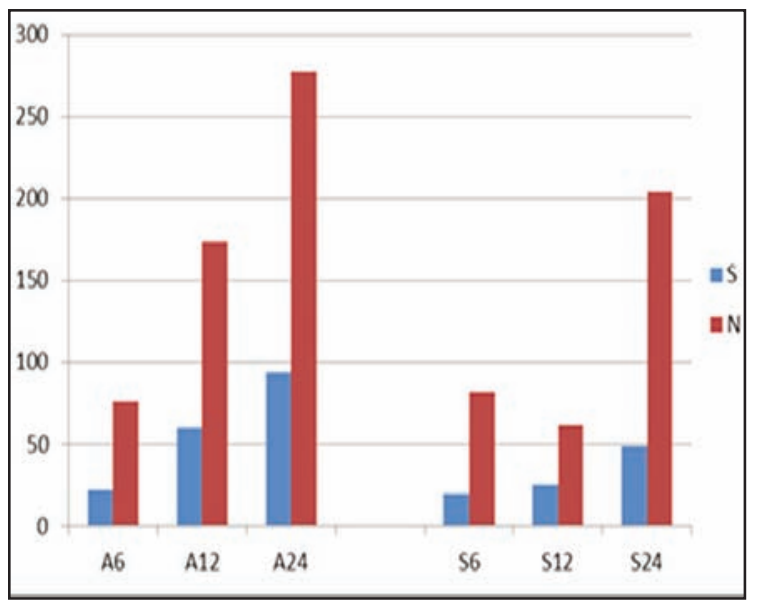

Figure 4. Total number of benthic mollusc species, $\mathrm{S}$, and individuals, $\mathrm{N}$, according to season (A: autumn; $\mathrm{S}$ : spring) and bathymetric level $(6,12,24 \mathrm{~m})$.

the north-western Mediterranean (Scaperrotta et al., 2018), Ustica, South Tyrrhenian (Micali, 2016) and north-eastern Ionian (Romani et al., 2018). This poorly known species, which might be widely distributed in the Mediterranean, had not been reported before now from the MS, nor from the contiguous Tyrrhenian basin.

Sinezona semicostata Burnay et Rolán, 1990, accepted as valid species after Geiger (2012 a, b), is considered as a characteristic Macaronesian species, recently recorded in the Mediterranean by Micali \& Geiger (2015) from Linosa, and by Romani et al. (2017) from Corfù and Scilla. The present record confirmed the not occasional occurrence at Scilla and, more in general, in the MS area.

The pearl oyster, Pinctada imbricata radiata (Leach, 1814), a long-term naturalized Lessepsian, is the only species of eastern origin here reported from Scilla. The simultaneous occurrence, both at south (Giacobbe \& Renda, 2018) and north ends of the MS, might foreshadow the establishment of a bridgehead for further diffusion in the Tyrrhenian basin. We mention, at last, the small bivalve Lasaea adansoni, as a species never reported in Scilla, despite its wide Mediterranean distribution.

\section{Plancton species}

A total of 927 specimens testified the occurrence of 14 planktonic taxa, accidentally trapped

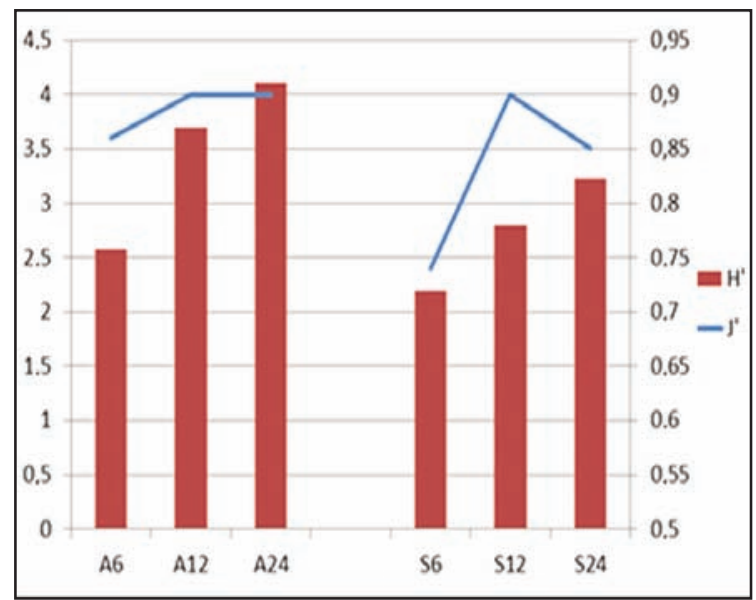

Figure 5. Shannon diversity index, H', and Equitability J', according to season (A: autumn; S: spring) and bathymetric level $(6,12,24 \mathrm{~m})$.

by algal covering, here reported as a contribution to the knowledge of the overall mollusc diversity in the Scilla area. They included the Littorinimorpha Atlanta brunnea J.E. Gray, 1850, A. helicinoidea J.E. Gray, 1850, A. inflata J.E. Gray, 1850, A. lesuerii J.E. Gray, 1850, A. peronii Lesueur, 1817, Oxygyrus inflatus Benson, 1835 and Protatlanta souleyeti (E.A. Smith, 1888); the Pteropoda Cavolinia inflexa (Lesueur, 1813), Clio pyramidata Linnaeus, 1767 and Creseis clava (Rang, 1828); the Thecosomata Heliconoides inflatus (d'Orbigny, 1835), Limacina trochiformis (d'Orbigny, 1835), Peracle diversa (Monterosato, 1875), P. reticulata (d'Orbigny, 1835) and Styliola subula (Quoy et Gaimard, 1827).

All Atlanta species had a circumtropical distribution that includes the Mediterranean Sea, but while $A$. peronii and A. lesuerii are known in the whole Mediterranean, A. inflata has been reported only in the western basins, differently from $A$. brunnea and A. helicinoidea which are confined in the eastern basins (Wall-Palmer et al., 2018). This latter taxon is confirmed for the Italian seas, after a first ascertained record from Scilla (Giacobbe \& Renda, 2018). The other atlantidae, Oxygyrus inflatus and Protatlanta souleyeti, respectively characterize the central-western and central-eastern Mediterranean.

The occurrence in the MS of the panoceanic pteropoda Cavolinia inflexa and Clio pyramidata, and the amphi-atlantic Creseis clava, has been con- 
firmed in agreement with Guglielmo et al. (1995), although authoritative sites like WoRMS do not report such species in the central Mediterranean (marinespecies.org/aphia.php? $p=$ taxdetails $\& \mathrm{id}=605988 \#$ distributions). A disjoined distribution was also represented by the Thecosomata $\mathrm{Li}$ macina trochiformis (Rampal, 2017), Styliola subula, and the epibathyal Peracle reticulata (Rampal, 1975, 2011), whose prior absence in the central Mediterranean might be due to a low investigation effort. Heliconoides inflatus in the Mediterranean is known in the western basins. Peracle diversa, although distributed in the whole Mediterranean, is here reported for the first time in the MS area.

\section{DISCUSSION AND CONCLUSIONS}

A recent review of the Mediterranean benthic mollusc biodiversity (Sabelli \& Taviani, 2014), reporting data of Vazzana (2010), has accredited 396 gastropod and 97 bivalve species from the Scilla seafloors. This large amount of species, however, did not describe the local biodiversity, because almost entirely based on shell remains whose origin cannot be verified, similarly to some recently described species whose actual habitat remains unknown (Pusateri et al., 2012; Romani \& Scuderi, 2015; Pusateri et al., 2017; etc.). The shallow subtidal habitat of some scarcely known species which have been reported from the same locality has been instead adequately described (Scuderi \& Reitano, 2012), as well as that of some non-indigenous taxa (Stasolla et al., 2014). The lack of contextualized data might explain the absence of Scilla and, more in general, of MS, in the recent review of Poursanidis et al. (2016) about the molluscan fauna from the Mediterranean biocoenosis of photophilic algae. The paper, based on dataset updated to the 2012, reported distribution records for 599 species, about fifty of which, in our opinion, should be rejected as not compatible with the Infralittoral rocky shore habitat. The present investigation on the Scilla cliff, that adds 63 more taxa (three polyplacophorans, fifty gastropods, and ten bivalves) to the Poursanidis dataset, remarkably increased the known amount of species which may be found in the Mediterranean photophilic rocky cliff. All these species, nevertheless, cannot be indiscriminately assigned to such habitat, since some of these are ubiquitous taxa, organisms of other habitats settled in micro-enclaves, or juveniles of species structurally extraneous to the photophilic algae environment. The role of algal covering as larvae collector from disparate habitats (Antit et al., 2013; Lolas et al., 2018), in fact, is here proved by the high occurrence of planktonic molluses in all the examined samples.

Benthic mollusc diversity of photophilic algae from Scilla may be considered very high, in comparison with other areas at comparable latitudes (Chemello \& Russo, 1998; Milazzo et al., 2000; Badalamenti et al., 2002; Terlizzi et al., 2003), independently from their protection regime. Inside the MS, the number of species from Scilla is about twice as many as those recently reported for Capo d'Armi, although the number of individuals was almost equivalent (Giacobbe \& Renda, 2018). The number of species which significantly contributed to the mollusc taxocoenosis is also higher at Scilla than at Capo d'Armi. Seasonality, characterized by more species and individuals in autumn rather than in spring, has suggested a relatively late larval recruitment. Depth scarcely affected the species distribution, probably due to water transparency, thermal homogeneity, and nutrient mixing (Azzaro et al., 2007).

The whole mollusc taxocoene showed a marked western footprint, in accordance with the known biogeographic peculiarities which include "Pliocene Atlantic remnants and local endemisms" (Bianchi, 2007, and literature herein cited).

Pelagic molluscs, instead, similarly to that observed at the south-eastern mouth of the MS (Giacobbe \& Renda, 2018), included species known to be localized in the eastern basin, in accordance with the constant upwelling of the Levantine Intermediate Waters, LIW.

\section{ACKNOWLEDGMENTS}

We wish to thank Franck Boyer (Garrigues Sainte Eulalie, France), Francesco Pusateri (Palermo, Italy), and Italo Nofroni (Roma, Italy) for thier suggestions and precious contribution in species determination, and Daniel Geiger (USA) for confirmation on the variability of Sinezona cingulata (Figs. 9-11). 
POLYPLACOPHORA Gray, 1821

LEPTOCHITONIDAE Dall, 1889

Leptochiton cfr cancellatus (Sowerby, 1840)

Leptochiton cimicoides (Monterosato, 1879)

POLYPLACOPHORA Gray, 1821

ACANTHOCHITONIDAE Simroth, 1894

Acanthochitona crinita (Pennant, 1777 )

GASTROPODA Cuvier, 1795

FISSURELLIDAE Fleming, 1822

Diodora graeca (Linnaeus, 1758)

Emarginula huzardii Payraudeau, 1826

Emarginula tenera Locard, 1891

ANATOMIDAE McLean, 1989

Anatoma micalii Geiger, 2012

SCISSURELLIDAE Gray, 1847

Scissurella costata D'Orbigny, 1824

Sinezona cingulata (O.G. Costa, 1861) (Figs. 6-10)

Sinezona semicostata Burnay et Rolán, 1990 (Fig. 10)

HALIOTIDAE Rafinesque, 1815

Haliotis tuberculata tuberculata Linnaeus, 1758

TROCHIDAE Rafinesque, 1815

Gibbula guttadauri (Philippi, 1836)

Gibbula turbinoides (Deshayes, 1835)

Jujubinus striatus striatus (Linnaeus, 1758)

Clanculus cruciatus (Linnaeus, 1758)

CALLIOSTOMATIDAE Thiele, 1924 (1847)

Calliostoma sp.

Calliostoma conulus (Linnaeus, 1758)

Calliostoma laugieri (Payraudeau, 1826)

SKENEIDAE Clark W., 1851

Dikoleps nitens (Philippi, 1844)

Dikoleps umbilicostriata (Gaglini, 1987)

Skenea catenoides (Monterosato, 1877)

Skeneoides exilissima (Philippi, 1844)

PHASIANELLIDAE Swainson, 1840

Tricolia deschampsi Gofas, 1993 (Fig. 11)

Tricolia landinii Bogi et Campani, 2007

Tricolia speciosa (Von Muhelfeldt, 1824)

NERITIDAE Rafinesque, 1815

Smaragdia viridis (Linnaeus, 1758)

CERITHIIDAE Fleming, 1822

Bittium lacteum (Philippi, 1836)

Bittium latreillii (Payraudeau, 1826)

Bittium reticulatum (da Costa, 1778)

Cerithidium submammillatum (De Rayneval et Ponzi, 1854)
Cerithium renovatum Monterosato, 1884

Cerithium vulgatum vulgatum Bruguiere, 1792

PLANAXIDAE Gray, 1850

Fossarus ambiguus (Linnaeus, 1758)

TURRITELLIDAE Lovén, 1847

Turritella turbona Monterosato, 1887

TRIPHORIDAE J. E. Gray, 1847

Marshallora sp.

Monophorus thiriotae Bouchet, 1985

Similiphora similior (Bouchet et Guillemot, 1978)

Metaxia metaxa (Delle Chiaie, 1828)

CERITHIOPSIDAE H. Adams et A. Adams, 1853

Krachia tiara (Monterosato, 1874)

Cerithiopsis micalii (Cecalupo et Villari, 1997)

Cerithiopsis minima (Brusina, 1865)

Cerithiopsis pulchresculpta Cachia, Mifsud et Sammut, 2004

Cerithiopsis scalaris Locard,1891

Cerithiopsis sp.

Cerithiopsis tubercularis (Montagu, 1803)

EPITONIIDAE Berry, 1910 (1812)

Epitonium algerianum (Weinkauff, 1866)

EULIMIDAE Philippi, 1853

Melanella boscii (Payraudeau, 1826)

Melanella polita (Linnaeus, 1758)

Parvioris ibizenca (Nordsiek, 1968)

Vitreolina curva (Monterosato, 1874)

Vitreolina incurva (Bucquoy, Dautzenberg et Dollfus, 1883)

Vitreolina cfr incurva

Vitreolina perminima (Jeffreys, 1883)

Vitreolina philippi (de Rayneval \& Ponzi, 1854)

Vitreolina sp.

Nanobalcis nana (Monterosato, 1878)

Curveulima devians (Monterosato, 1884)

CINGULOPSIDAE Fretter et Patil, 1958

Eatonina ochroleuca (Brusina, 1869)

Eatonina pumila (Monterosato, 1884)

RISSOINIDAE Stimpson, 1865

Rissoina bruguieri (Payraudeau, 1826)

RISSOIDAE Gray, 1847

Rissoa similis Scacchi, 1836

Alvania cancellata (da Costa, 1778)

Alvania cimex (Linnaeus, 1758)

Alvania clathrella L. Seguenza, 1903

Alvania discors (T. Allan, 1818)

Alvania geryonia (Nardo, 1847)

Alvania hirta Monterosato, 1884

Alvania hispidula (Monterosato, 1884)

Alvania lanciae (Calcara, 1845)

Alvania lineata Risso, 1826 
Alvania rudis (Philippi, 1844)

Alvania scabra (Philippi, 1844)

Alvania sp.

Alvania spinosa (Monterosato, 1890)

Alvania subcrenulata (Bucquoy, Dautzenberg et Dollfus, 1884)

Alvania weinkauffi jacobusi Oliverio, Amati et Nofroni, 1986

Crisilla beniamina (Monterosato, 1884)

Peringiella elegans (Locard, 1891)

Pusillina inconspicua (Alder, 1844)

Pusillina lineolata (Michaud, 1832)

Pusillina marginata (Michaud, 1830)

Setia amabilis (Locard, 1886)

Setia ambigua (Brugnone, 1873) (Fig. 12)

Setia homerica Romani \& Scuderi, 2015

Setia maculata (Monterosato, 1869)

Setia cfr turriculata Monterosato, 1884

Setia turriculata Monterosato, 1884

Setia sp. (Fig. 13)

ANABATHRIDAE Keen, 1971

Pisinna glabrata (Von Muehlfeld, 1824)

BARLEEIIDAE J.E. Gray, 1857

Barleeia unifasciata (Montagu, 1803)

CAECIDAE Gray, 1850

Caecum armoricum de Folin, 1869

Caecum auriculatum de Folin, 1868

Caecum clarkii Carpenter, 1859

Caecum subannulatum de Folin, 1870

Caecum trachea (Montagu, 1803)

VERMETIDAE Rafinesque, 1815

Thylaeodus semisurrectus (Bivona-Bernardi, 1832)

Dendropoma cristatum (Biondi, 1859)

CALYPTRAEIDAE Lamarck, 1809

Crepidula aculeata (Gmelin, 1791)

Calyptraea chinensis (Linnaeus, 1758)

CYPRAEIDAE Rafinesque, 1815

Luria lurida (Linnaeus, 1758)

Naria spurca spurca (Linnaeus, 1758)

NATICIDAE Guilding, 1834

Notocochlis dillwynii (Payraudeau, 1826)

Euspira guillemini (Payraudeau, 1826)

Natica sp.

ATLANTIDAE Rang, 1829

Protatlanta souleyeti (E.A. Smith, 1888)

Atlanta brunnea J.E. Gray, 1850 (Fig. 14)

Atlanta helicinoidea J.E. Gray, 1850 (Fig. 15)

Atlanta lesuerii J.E. Gray, 1850

Atlanta peronii Lesueur, 1817

Oxygyrus inflatus Benson, 1835
MURICIDAE Rafinesque, 1815

Hexaplex (Trunculariopsis) trunculus trunculus (Linnaeus, 1758)

Ocenebra edwardsii (Payraudeau, 1826)

Ocinebrina aciculata (Lamarck, 1822)

Muricopsis (Muricopsis) cristata (Brocchi, 1814)

Coralliophila meyendorffii (Calcara, 1845)

GRANULINIDAE Boyer, 2017

Granulina marginata (Bivona, 1832)

CYSTISCIDAE Stimpson, 1865

Gibberula cristinae Tisselli, Agamennone \& Giunchi 2009

Gibberula cfr cristinae

Gibberula philippi (Monterosato, 1878)

Gibberula recondita Monterosato, 1844

Gibberula sp.

MITRIDAE Swainson, 1829

Episcomitra cornicula (Linnaeus, 1758)

COSTELLARIIDAE MacDonald, 1860

Pusia savignyi (Payraudeau, 1826)

Pusia tricolor (Gmelin, 1791)

BUCCINIDAE Rafinesque, 1815

Euthria cornea Linnaeus, 1758

Chauvetia affinis (Monterosato, 1889)

Chauvetia brunnea (Donovan, 1804)

Chauvetia lefebvrii (Maravigna, 1840)

Chauvetia mamillata (Risso, 1826)

Chauvetia recondita (Brugnone, 1873)

Chauvetia turritellata (Deshayes, 1835)

Chauvetia ventrosa Nordsieck, 1976

Enginella leucozona (Philippi, 1844)

Aplus scaber (Locard, 1891)

COLUBRARIIDAE Dall, 1904

Cumia reticulata (Blainville, 1829)

NASSARIIDAE Iredale, 1916 (1835)

Tritia cuvierii (Payraudeau, 1826)

COLUMBELLIDAE Swainson, 1840

Columbella rustica (Linnaeus, 1758)

Mitrella coccinea (Philippi, 1836)

Mitrella minor (Scacchi, 1836)

Mitrella scripta (Linnaeus, 1758)

Mitrella svelta Kobelt, 1889

FASCIOLARIIDAE Gray, 1853

Fusinus dimassai Buzzurro et Russo, 2007

MITROMORPHIDAE Casey, 1904

Mitromorpha (Mitrolumna) columbellaria (Scacchi, 1836)

Mitromorpha (Mitrolumna) karpathensis (Nordsieck, 1969)

CLATHURELLIDAE H. Adams et A. Adams, 1858

Clathromangelia granum (Philippi, 1844) 
CONIDAE Fleming, 1822

Conus ventricosus Gmelin, 1791

RAPHITOMIDAE Bellardi, 1875

Raphitoma contigua (Monterosato, 1884)

Raphitoma cfr echinata

Raphitoma laviae (Philippi, 1844)

Raphitoma leufroyi (Michaud, 1828)

Raphitoma linearis (Montagu, 1803)

MANGELIIDAE P. Fischer, 1883

Mangelia multilineolata (Deshayes, 1835)

Mangelia striolata Risso, 1826

Mangelia taeniata (Deshayes, 1835)

Mangelia unifasciata (Deshayes, 1835)

Mangelia vauquelini (Payraudeau, 1826)

RISSOELLIDAE Gray, 1850

Rissoella diaphana (Alder, 1848)

Rissoella globularis (Forbes et Hanley, 1853)

Rissoella opalina (Jeffreys, 1848)

OMALOGYRIDAE G.O. Sars, 1878

Ammonicera fischeriana (Monterosato, 1869)

Ammonicera nodulosa Oliver et Rolàn 2015 (Fig. 16)

Ammonicera rota (Forbes et Hanley, 1850) (Fig. 17)

Omalogyra simplex (Costa OG, 1861)

PYRAMIDELLIDAE J.E. Gray, 1840

Brachystomia carrozzai (van Aartsen, 1987)

Brachystomia eulimoides (Hanley, 1844)

Odostomia kromi van Aartsen, Menkhorst et Gittenberger, 1984

Odostomia lukisii Jeffreys, 1859

Odostomia sp.

Odostomia striolata Forbes et Hanley, 1850

Megastomia conoidea (Brocchi, 1814)

Ondina sp.

Parthenina clathrata (Jeffreys, 1848)

Parthenina decussata (Montagu, 1803)

Parthenina emaciata (Brusina, 1866)

Parthenina interstincta (Adams J., 1797)

Parthenina monozona (Brusina, 1869)

Odostomella doliolum (Philippi, 1844)

Turbonilla hamata Nordsieck, 1972

Turbonilla lactea (Linnaeus, 1758)

Turbonilla multilirata (Monterosato, 1875)

Turbonilla obliquata (Philippi, 1844)

Turbonilla pumila Seguenza G., 1876

Turbonilla pusilla (Philippi, 1844)

Dunkeria jeffreysi (Jeffreys, 1848)

Pyrgiscus rufus (Philippi, 1836)

Pyrgostylus striatulus (Linnaeus, 1758)

Eulimella acicula (Philippi, 1836)

MURCHISONELLIDAE Casey, 1904

Ebala nitidissima (Montagu, 1803)

Ebala pointeli (de Folin, 1868)
BULLIDAE Gray, 1827

Bulla striata Bruguiere, 1792

RETUSIDAE Thiele, 1925

Retusa mammillata (Philippi, 1836)

Retusa truncatula (Bruguiere, 1792)

Retusa laevisculpta (Granata-Grillo, 1877) (Fig. 18)

Pyrunculus hoernesii (Weinkauff, 1866) (Fig. 19)

HAMINOEIDAE Pilsbry, 1895

Haminoea sp.

Atys macandrewii E. A.Smith, 1872

Weinkauffia turgidula (Forbes, 1844)

PHILINIDAE Gray, 1850 (1815)

Philine catena (Montagu, 1803)

CAVOLINIIDAE Gray, 1850 (1815)

Cavolinia inflexa (Lesueur, 1813)

CLIIDAE Jeffreys, 1869

Clio pyramidata Linnaeus, 1767

CRESEIDAE Rampal, 1973

Creseis clava (Rang, 1828)

Styliola subula (Quoy et Gaimard, 1827)

LIMACINIDAE Gray, 1840

Limacina (Munthea) trochiformis (D’Orbigny, 1835)

Heliconoides inflatus (d'Orbigny, 1835)

PERACLIDAE Tesch, 1913

Peracle diversa (Monterosato, 1875)

Peracle reticulata (D'Orbigny, 1835)

OXYNOIDAE Stoliczka, 1868 (1847)

Lobiger serradifalci (Calcara, 1840)

VOLVATELLIDAE Pilsbry, 1895

Ascobulla fragilis (Jeffreys, 1856)

PLEUROBRANCHIDAE

Berthella cfr aurantiaca (Risso, 1818)

APLYSIIDAE Lamarck, 1809

Aplysia (Pruvotaplysia) parvula Mörch, 1863 (Fig. 20)

Petalifera petalifera (Rang, 1828) (Fig. 21)

SIPHONARIIDAE Gray, 1827

Williamia gussonii (Costa O.G., 1829)

ARCIDAE Lamarck, 1809

Arca noae Linnaeus, 1758

Asperarca secreta La Perna, 1998

BIVALVIA Linnaeus, 1758

NOETIIDAE Stewart, 1930

Striarca lactea (Linnaeus, 1758) 
MYTILIDAE Rafinesque, 1815 Mytilaster lineatus (Gmelin, 1791)

Musculus costulatus (Risso, 1826)

Rhomboidella prideauxi (Leach, 1815)

Lithophaga lithophaga (Linnaeus, 1758)

Dacrydium hyalinum Monterosato, 1875

Modiolula phaseolina (Philippi, 1844)

PINNIDAE Leach, 1819

Pinna sp.

PTERIIDAE Gray, 1847 (1820)

Pinctada imbricata radiata (Leach, 1814)

PECTINIDAE Rafinesque, 1815

Flexopecten hyalinus (Poli, 1795)

Aequipecten sp.

Palliolum incomparabile (Risso, 1826)

LIMIDAE Rafinesque, 1815

Lima lima (Linnaeus, 1758)

Limaria hians (Gmelin, 1791)

LUCINIDAE Fleming, 1828

Ctena decussata (Costa O.G., 1829)

CHAMIDAE Lamarck, 1809

Chama gryphoides Linnaeus, 1758

LASAEIDAE Gray, 1842

Lasaea adansoni (Gmelin, 1791)
MONTACUTIDAE W. Clark, 1855

Epilepton cfr clarkiae (W. Clark, 1852)

CARDITIDAE Férussac, 1822

Cardita calyculata (Linnaeus, 1758)

Centrocardita aculeata (Poli, 1795)

Glans trapezia (Linnaeus, 1767)

CARDIIDAE Lamarck, 1809

Parvicardium scriptum (Bucquoy, Dautzenberg et Dollfus, 1892)

Papillicardium papillosum (Poli, 1791)

TELLINIDAE Blainville, 1814

Arcopella balaustina (Linnaeus, 1758)

VENERIDAE Rafinesque, 1815

Gouldia minima (Montagu, 1803)

Irus irus (Linnaeus, 1758)

Lajonkairia lajonkairii (Payraudeau, 1826)

HIATELLIDAE Gray, 1824

Hiatella arctica (Linnaeus, 1767)

SCAPHOPODA Bronn, 1862

DENTALIIDAE Children, 1834

Antalis sp.

Table 1. The mollusc from the photophilic zone of Scilla cliff (Strait of Messina, Central Mediterranean).

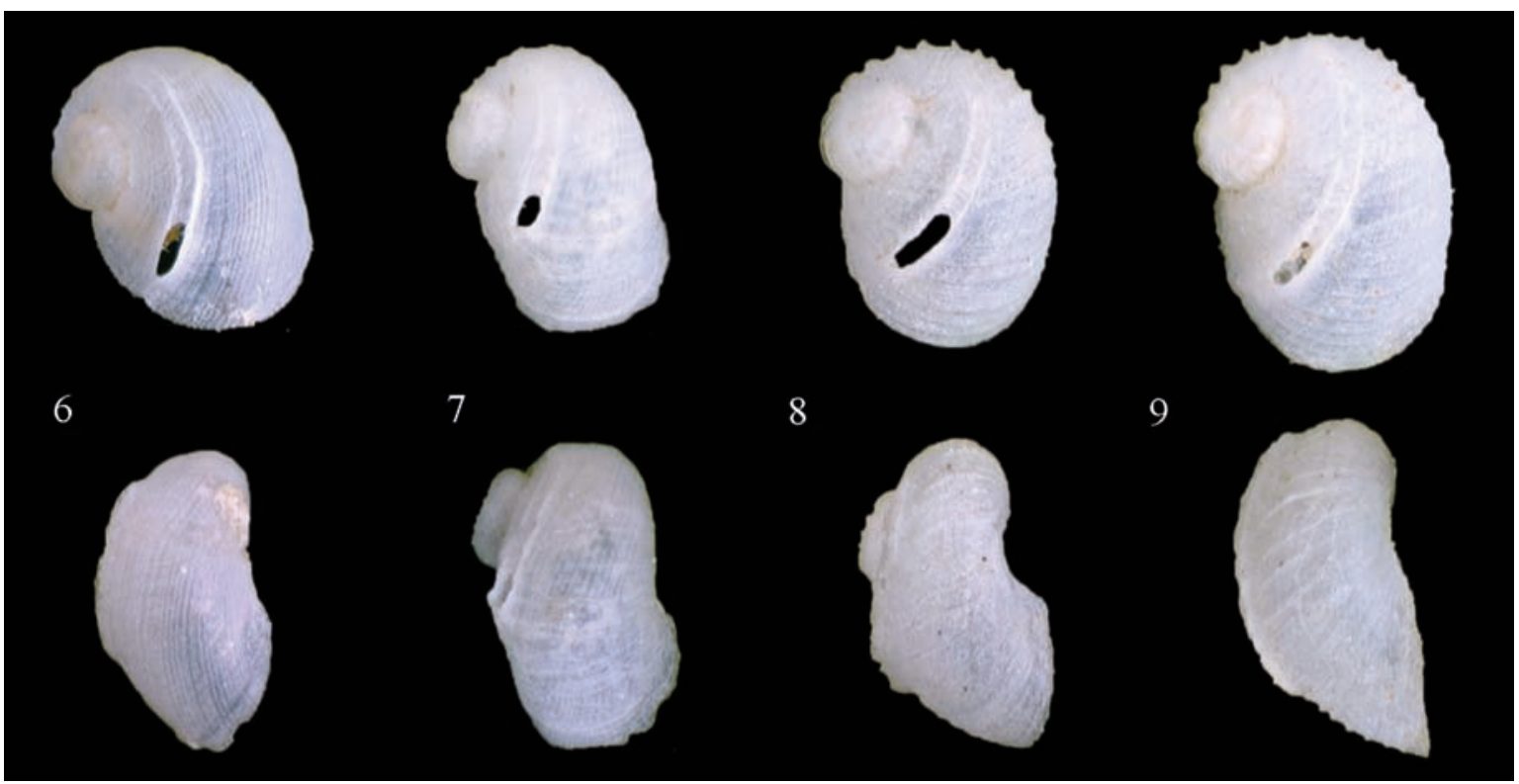

Figures 6-9. Scilla cliff (Strait of Messina, Central Mediterranean): Sinezona cingulata (O.G. Costa, 1861). 


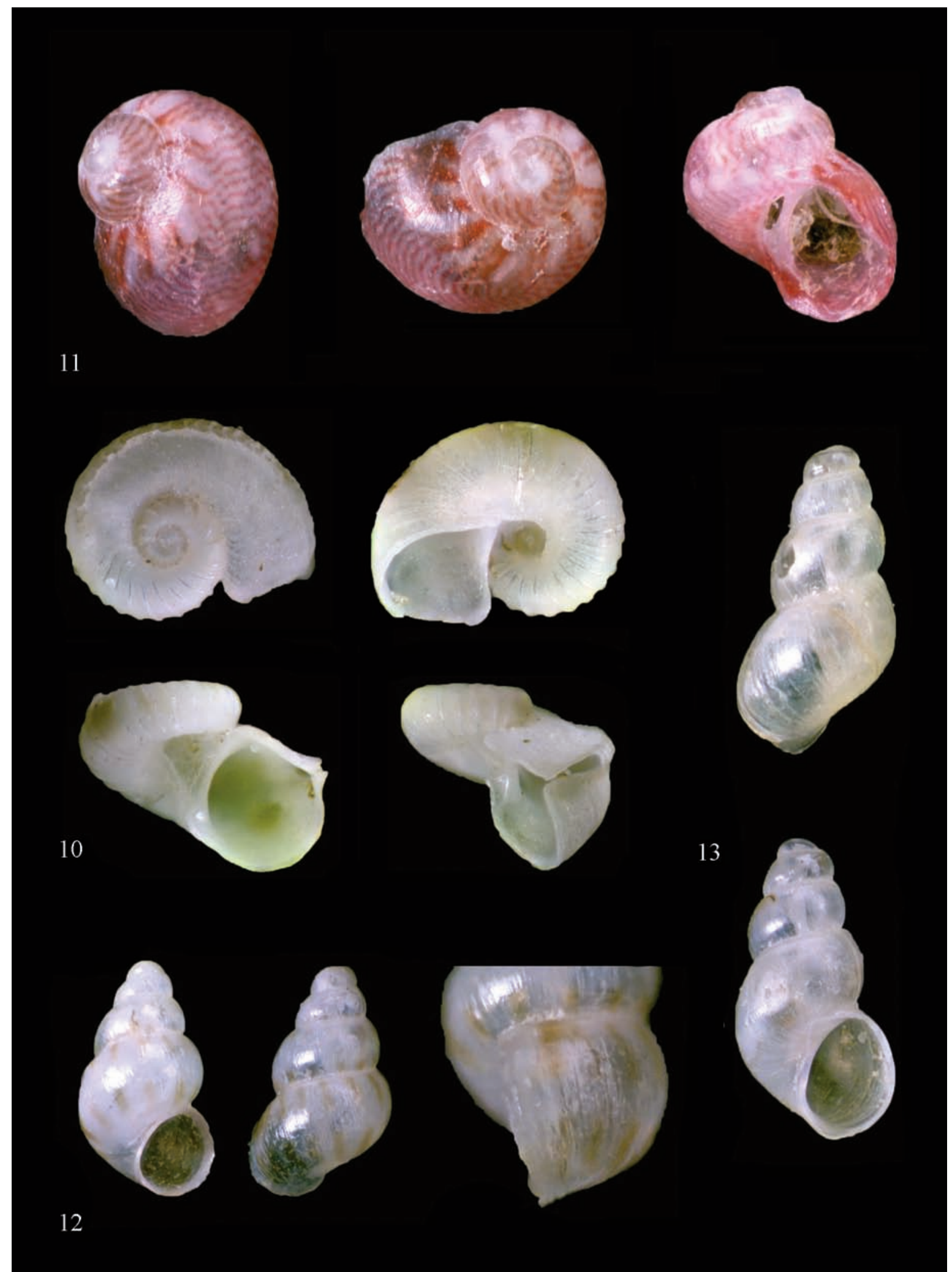

Figures 10-13. Scilla cliff (Strait of Messina, Central Mediterranean). Fig. 10: Sinezona semicostata Burnay et Rolán, 1990. Fig. 11: Tricolia deschampsi Gofas, 1993. Fig. 12: Setia ambigua (Brugnone, 1873). Fig. 13. Setia sp. 


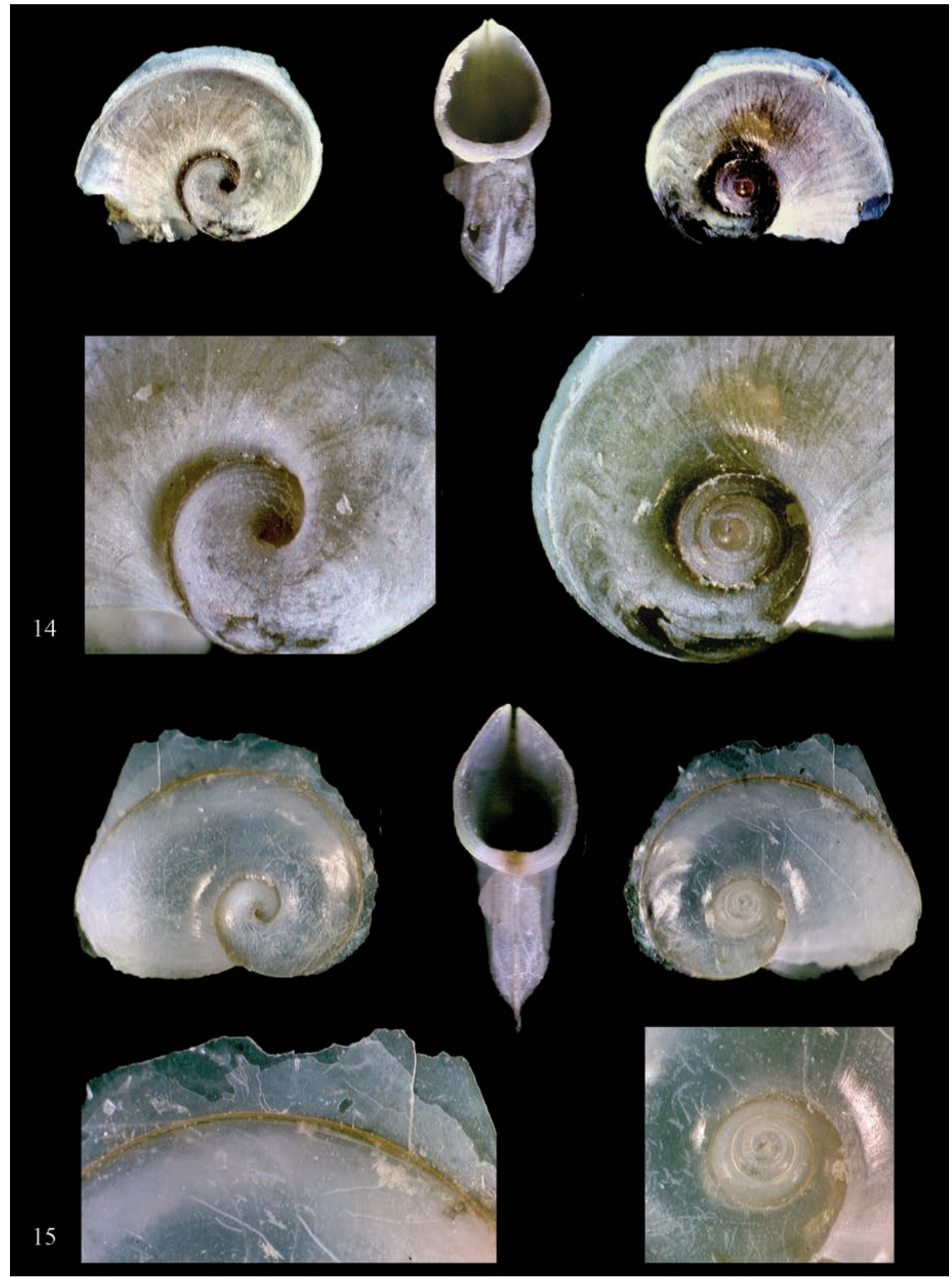

Figures 14, 15. Scilla cliff (Strait of Messina, Central Mediterranean)

Fig. 14: Atlanta brunnea J.E. Gray, 1850. Fig. 15: Atlanta helicinoidea J.E. Gray, 1850 


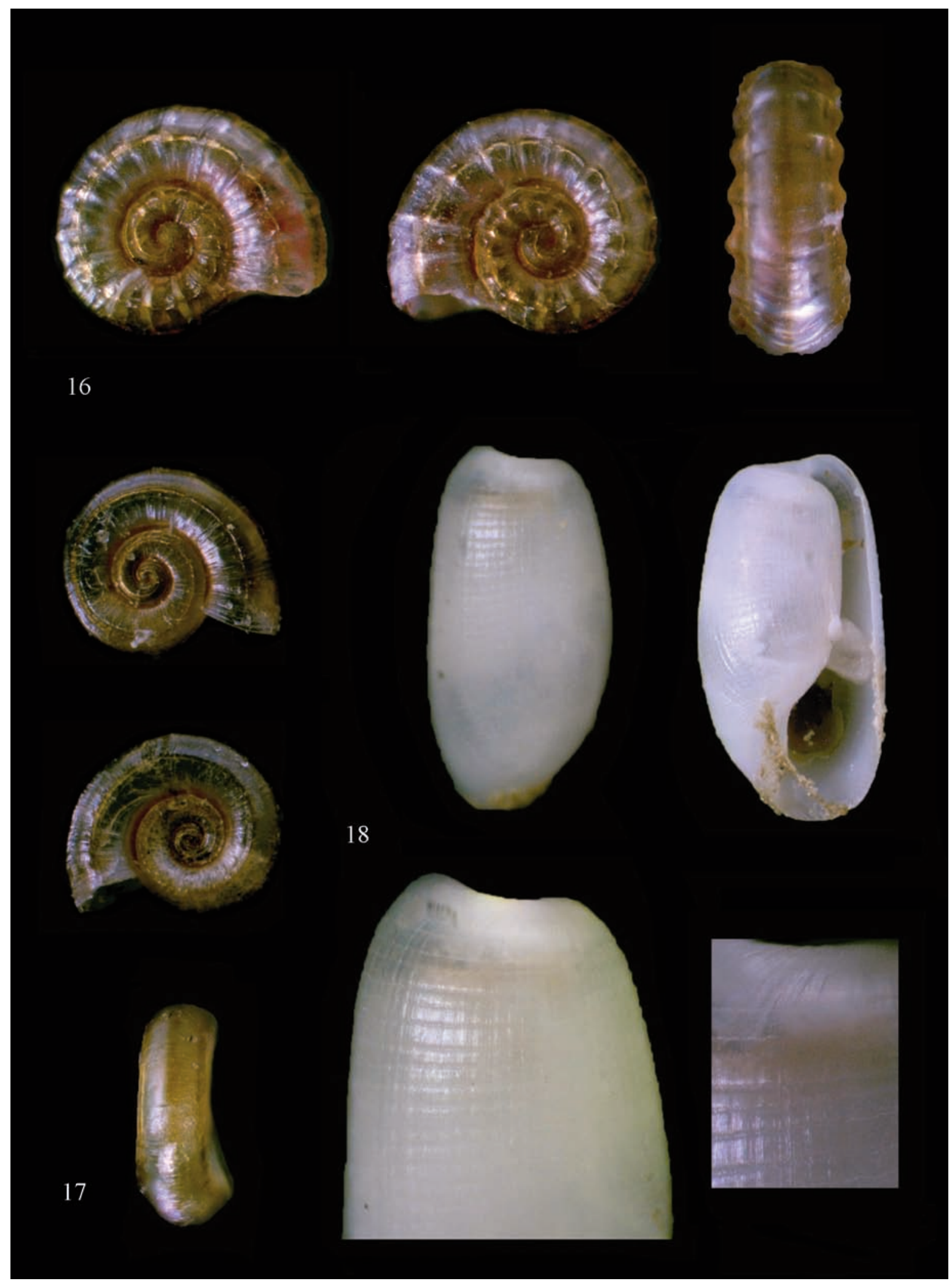

Figures 16-18. Scilla cliff (Strait of Messina, Central Mediterranean). Fig. 16: Ammonicera nodulosa Oliver et Rolàn 2015. Fig. 17: Ammonicera rota (Forbes et Hanley, 1850). Fig. 18: Retusa laevisculpta (Granata-Grillo, 1877). 


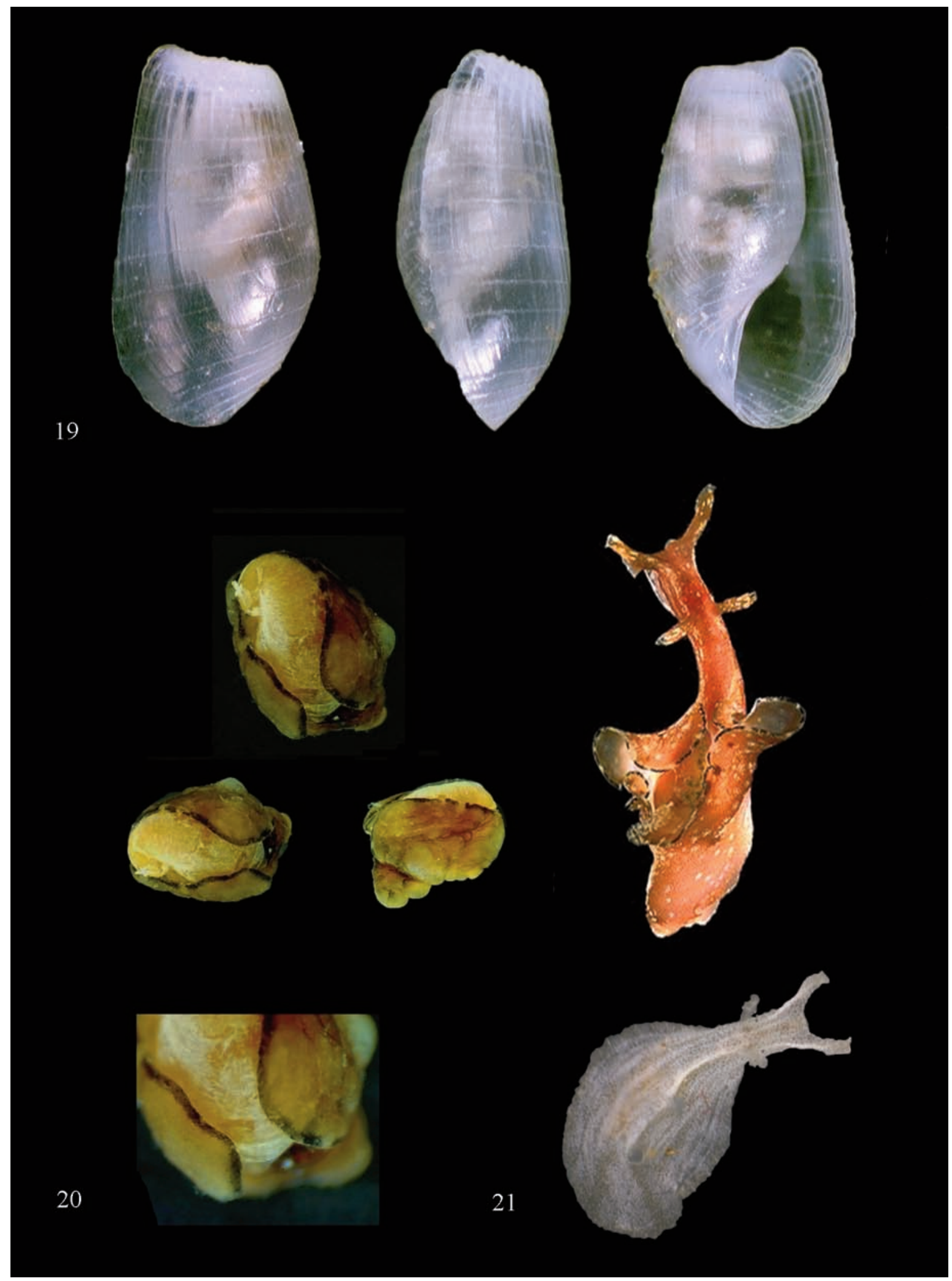

Figures 19-21. Scilla cliff (Strait of Messina, Central Mediterranean). Figure 19. Pyrunculus hoernesii (Weinkauff, 1866). Fig. 20: Aplysia (P.) parvula Mörch, 1863. The image of a living specimen, shown for comparison, was extracted from www.seaslugforum.net/find/aplyparv). Fig. 21: Petalifera petalifera (Rang, 1828). 


\section{REFERENCES}

Androsov S.A., Vol'tsinger N. Ye. \& Kagan B.A., 1996. The Messina whirls in the present and past. Atmospheric and Oceanic Physics, English Translation, 31: 650-662.

Antit M., Daoulatli A., Rueda J.L. \& Salas C., 2013. Temporal variation of the algae-associated molluscan assemblage of artificial substrata in the Bay of Tunis (Tunisia). Mediterranean Marine Science, 14: 390 402. DOI: http://dx.doi.org/10.12681/mms.379

Azzaro F., Decembrini F., Raffa F. \& Crisafi E., 2007. Seasonal variability of phytoplankton fluorescence in relation to the Straits of Messina (Sicily) tidal upwelling. Ocean Science Discussions, 4: 415-440, www. ocean-sci-discuss.net/4/415/2007/.

Badalamenti F., Chemello R., D'Anna G., Henriquez Ramos P. \& Riggio S., 2002. Are artificial reefs comparable to neighbouring natural rocky areas? A mollusc case study in the Gulf of Castellammare (NW Sicily). ICES Journal of Marine Science, 59: 127131. DOI:10.1006/jmsc.2002.1265.

Bianchi C.N., 2007. Biodiversity issues for the forthcoming tropical Mediterranean Sea. Hydrobiologia 580: 7. DOI: $10.1007 / \mathrm{s} 10750-006-0469-5$

Bianchi C.N., Morri C., Chiantore M., Montefalcone M., Parravicini V. \& Rovere A., 2012. Mediterranean Sea biodiversity between the legacy trom The Past and a future of change. In: Life in the Mediterranean Sea: A Look at Habitat Changes. Editor: Noga Stambler, $55 \mathrm{pp}$.

Bogi C. \& Campani E., 2007. Tricolia landinii, una nuova specie per le coste orientali della Sicilia. Iberus 25: 27-31.

Bogi C. \& Bartolini S., 2008). Xylodiscula wareni n. sp., una nuova specie per le coste orientali della Sicilia. Iberus, 26: 43-46.

Boyer F., Pelorce J. \& Hoarau A., 2002. Le genre Granulina sur le littoral de Ia Cote d'Azur: récolt e observations. Bollettino Malacologico, 39: 165-170.

Buzzurro G. \& Russo P., 2007. Fusinus del Mediterraneo. Published by the authors, $280 \mathrm{pp}$.

Casalbore D., Bosman A., Ridente D. \& Chiocci F.L., 2014. Coastal and submarine landslides in the tectonically-active Tyrrhenian Calabrian margin (Southern Italy): examples and geohazard implications In: Krastel et al (Eds.) Submarine mass movements and their consequences, 6th International symposium, advances in natural and technological hazards research, 37: $261-269$

Chemello R. \& Russo G.F., 1998. The molluscan Taxocoene of photophilic algae from the Island of Lampedusa (strait of Sicily, southern Mediterranean). Bollettino Malacologico, 33: 95-104.

Cosentino A. \& Giacobbe S., 2015. Mollusc assemblages of hard bottom subtidal fringe: a comparison between two coastal typologies. Biodiversity Journal, 6: 353364.

Crocetta F., Renda W. \& Vazzana A., 2009. Alien Mollusca along the Calabrian shores of the Messina Strait area and a review of their distribution in the Italian seas. Bollettino Malacologico, 45: 15-30.

Ferranti L., Monaco C., Antonioli F., Maschio L., Kershaw S. \& Verrubbi V., 2007. The contribution of regional uplift and coseismic slip to the vertical crustal motion in the Messina Straits, southern Italy: Evidence from raised Late Holocene shorelines. Journal of Geophysical Research Atmospheres, 112: (B06401). DOI: 10.1029/2006JB004473

Geiger D.L., 2012. Monograph of the little slit shells. Volume 1. Introduction, Scissurellidae. pp. 1-728. Volume 2. Anatomidae, Larocheidae, Depressizonidae, Sutilizonidae, Temnocinclidae. pp. 7291291. Santa Barbara Museum of Natural History Monographs. Number 7. [30 October 2012].

Giacobbe S. \& Renda W., 2018. Mollusc diversity in Capo d'Armi (Central Mediterranean Sea) subtidal cliff: a first, tardy, report. Biodiversity Journal, 9: 25-34.

Gofas S., 1990. Le genre Gibberula (Marginellidae) en Méditerranée. Lavori della Società Italiana di Malacologia, 23: 113-139.

Guglielmo L., Crescenti N., Costanzo G. \& Zagami G., 1995. Zooplankton and micronekton communities in the Straits of Messina. In: Guglielmo L., Manganaro A. \& De Domenico E. (Eds.), The Straits of Messina ecosystem. Proceedings Symposium held in Messina 4-6 April 1991, Messina pp. 247-270.

Lolas A., Antoniadou C. \& Vafidis D., 2018. Spatial variation of molluscan fauna associated with Cystoseira assemblages from a semi-enclosed gulf in the Aegean Sea. Regional Studies in Marine Science 19: 17-24.

Micali P. \& Geiger D.L., 2015. Additions and corrections to the Scissurellidae and Anatomidae (Gastropoda Vetigastropoda) of the Mediterranean Sea, with first record of Sinezona semicostata Burnay et Rolán, 1990. Biodiversity Journal, 6: 703-708.

Micali P., 2016. Prima segnalazione di Jordaniella nivosa (Montagu, 1803) (Gastropoda: Pyramidellidae) e seconda segnalazione di Gibberula jansseni van Aartsen, Menkhorst \& Gittenberger, 1984 (Gastropoda: Cystiscidae) per le coste italiane. Alleryana, 34: 39-41.

Milazzo M., Chemello R., Badalamenti F. \& Riggio S., 2000. Molluscan assemblages associated with photophilic algae in the Marine Reserve of Ustica Island (Lower Tyrrhenian Sea, Italy). Italian Journal of Zoology, 67: 287-295.

Mistri M. \& Ceccherelli V.U., 1994. Growth and secondary production of the Mediterranean gorgonian Paramuricea clavata. Marine Ecology Progress Series, 103: 291-296.

Mistri M. \& Ceccherelli V.U., 1995. Damage and partial mortality in the gorgonian Paramuricea clavata in 
the Strait of Messina (Tyrrhenian Sea). Marine Life, 5: 43-49.

Mistri M. \& Rossi R., 2000. Levels of taxonomic resolution and choice of transformation sufficient to detect community gradients: an approach to hard-substrata benthic studies. Italian Journal of Zoology, 67: 163-167.

Ortea J., Moro L., Bacallado J.J., Sanchez J.J., Telle A. \& Herrero R., 2009. Nuevas aportaciones al inventario de las babosas marinas del archipiélago canario (Mollusca: Opisthobranchia y Sacoglossa). Vieraea, 37: 105-117.

Öztürk B., Doğan A., Bitlis-Bakir B. \& Salman A., 2014. Marine molluscs of the Turkish coasts: An updated checklist. Turkish Journal of Zoology, 38: 1-148. http://hdl.handle.net/10.3906/zoo-1405-78.

Pusateri F., Giannuzzi Savelli R. \& Oliverio M., 2012. Revisione delle Raphitomidae mediterranee: su Raphitoma contigua (Monterosato, 1884) e Raphitoma spadiana n. sp., specie sorelle (Gastropoda, Conoidea). Iberus, 30: 41-52.

Pusateri F., Giannuzzi Savelli R. \& Stahlschmidt P., 2017. Description of a new species of the genus Raphitoma Bellardi, 1847 from the Mediterranean Sea (Mollusca Neogastropoda Conoidea Raphitomidae). Biodiversity Journal, 8: 205-210.

Poursanidis D., Koutsoubas D., Arvanitidis C. \& Chatzigeorgiou G., 2016. ReefMedMol: Mollusca from the infralittoral rocky shores - the biocoenosis of photophilic algae - in the Mediterranean Sea. Biodiversity Data Journal 4: e7516. DOI: 10.3897/BDJ.4. e7516.

Romani L. \& Scuderi D., 2015. A new species of Setia H. Adams et A. Adams, 1852 (Prosobranchia Caenogastropoda Rissoidae) from the Mediterranean Sea. Biodiversity Journal, 6: 843-850.

Romani L., Raveggi A., Scaperrotta M. \& Bartolini S., 2017. Nota sui micromolluschi marini conchiferi rinvenuti nei dintorni di Paleokastritsa (Corfù [Kerkyra] Grecia, Mar Ionio Nord-Orientale). Alleryana, 35: 24-26.

Romani L., Raveggi A., Scaperrotta M. \& Bartolini S., 2018. Contributo alla conoscenza della malacofauna marina delle isole adriatiche. 1 . Nota sui micromolluschi marini conchiferi rinvenuti sulla costa settentrionale dell'isola di Lastovo [Lagosta](Croazia, Mar Adriatico Sud-Orientale). Alleryana, 36: 1-22.

Sabelli B. \& Taviani M., 2014. The making of the Mediterranean molluscan biodiversity. In: S. Goffredo \& Z. Dubinsky (Eds.), The Mediterranean Sea:
Its history and present challenges, pp. 285-306. DOI 10.1007/978-94-007-6704-1_16.

Scaperrotta M., Bartolini S. \& Bogi C., 2011. Accrescimenti: stadi di accrescimento dei molluschi marini del Mediterraneo. L'Informatore Piceno, Ancona. Vol. III., 184 pp.

Scaperrotta M., Bartolini S. \& Bogi C., 2018. Accrescimenti: stadi di accrescimento dei molluschi marini del Mediterraneo. L'Informatore Piceno, Ancona. Vol. IX., 189 pp.

Scuderi D. \& Reitano A., 2012. New observations on the taxonomy, biology and distribution of Tricolia landinii Bogi et Campani, 2007 (Gastropoda Vetigastropoda). Biodiversity Journal, 3: 521-526.

Smriglio C. \& Mariottini P., 2013. Description of Granulina lapernai spec. nov. (Gastropoda, Marginellidae) from the Mediterranean Sea. Basteria, 77: 23-28.

Stasolla G., Riolo F., Macali A., Pierri C. \& Crocetta, F., 2014. Further spreading in the Italian seas of already established non-indigenous mollusc species. Marine Biodiversity Records. 7(e120). DOI: 10.1017/S17552 67214001079.

Terlizzi A., Scuderi D., Fraschetti S., Guidetti P. \& Boero F., 2003. Molluscs on subtidal clips: patterns of spatial distribution. Journal of the Marine Biological Association of the United Kingdom, 83: 165-172.

Tisselli M., Agamennone F. \& Giunchi L., 2009. Una nuova specie di Gibberula (Gastropoda: Cystiscidae) per il Mediterraneo. Bollettino Malacologico, 45: 4953.

Tringali L., 1993. Some remarks on Bulla hoernesii Weinkauff, 1866, and its systematic position. (Mollusca: Opisthobranchia: Cephalaspidea). Notiziario CISMA, 14: 23-28

Vazzana A., 2010. La malacofauna del Circalitorale di Scilla (Stretto di Messina). Bollettino Malacologico, 46: 65-74.

Vitale D., Giacobbe S., Spinelli A., De Matteo S. \& Cervera J.L., 2016. "Opisthobranch" (mollusks) inventory of the Faro lake: a Sicilian biodiversity hot spot. Italian Journal of Zoology, 83: 524-530. DOI: 10.1080/11250003.2016.1236843

Wall-Palmer D., Burridge A., Goetze E., Stokvis F., Janssen A., Mekkes L., Moreno-Alcántara M., Bednaršek N., Schiøtte T., Vinther Sørensen M., Smart C. \& Peijnenburg K. T.C.A, 2018. Biogeography and genetic diversity of the atlantid heteropods, Progress in Oceanography, Volume 160, Pages 1-25, DOI: 10.1016/j.pocean.2017.11.004 